\title{
Neurologic Defects and Selective Disruption of Basement Membranes in Mice Lacking Entactin-1/Nidogen-1
}

\author{
Lijin Dong, Yong Chen, Marcia Lewis, Jyh-Cheng Hsieh, Janet Reing, \\ J. Richard Chaillet, Carina Y. Howell, Mona Melhem, Sadayuki Inoue, \\ Jerry R. Kuszak, Koen DeGeest, and Albert E. Chung
}

Departments of Obstetrics and Gynecology and Biochemistry (LD, KD) and Departments of Ophthalmology and Pathology (JRK), Rush-Presbyterian-St. Luke's Medical Center, Chicago, Illinois; Department of Biological Sciences (YC, ML, J-CH, JR, JRC, CYH, AEC), University of Pittsburgh, and Department of Pathology (MM), VA Medical Center, Pittsburgh, Pennsylvania; and Department of Anatomy and Cell Biology (SI), McGill University, Montreal, Canada

\begin{abstract}
SUMMARY: Entactin-1 (nidogen-1) is an ubiquitous component of basement membranes. From in vitro experiments, entactin-1 was assigned a role in maintaining the structural integrity of the basement membrane because of its binding affinity to other components, such as type IV collagen and laminin. Entactin-1 also interacts with integrin receptors on the cell surface to mediate cell adhesion, spreading, and motility. Targeted disruption of the entactin-1 gene in the mouse presented in this study revealed a duplication of the entacin-1 locus. Homozygous mutants for the functional locus lacked entactin-1 mRNA and protein and often displayed seizure-like symptoms and loss of muscle control in the hind legs. The behavior patterns suggested the presence of neurologic deficits in the central nervous system, thus providing genetic evidence linking entactin-1 to proper functions of the neuromuscular system. In homozygous mutants, structural alterations in the basement membranes were found only in selected locations including brain capillaries and the lens capsule. The morphology of the basement membranes in other tissues examined superficially appeared to be normal. These observations suggest that the lost functions of entactin-1 result in pathologic changes that are highly tissue specific. (Lab Invest 2002, 82:1617-1630).
\end{abstract}

E ntactin-1, also known as nidogen-1, is a ubiquitous component of the basement membrane that was first characterized in mice (Durkin et al, 1988; Mann et al, 1989) and humans (Fazio et al, 1991; Nagayoshi et al, 1989; Olsen et al, 1989). Subsequently, homologs were identified and characterized in lower species, including ascidians (Nakae et al, 1993) and Caenorhabditis elegans (Kim and Wadsworth, 2000). Entactin-1 consists of three globular domains, two of which are within the amino terminus, with the third at the carboxyl end of the molecule separated from the amino-terminal globules by a rod-like structure that consists of cysteine-rich epidermal growth factor-like repeats and a thyroglobulin-like repeat (Durkin et al, 1995; Fox et al, 1991). The binding properties of entactin-1 suggest that it serves as a stabilizing bridge between the self-assembled layers of laminin and collagen IV that form the scaffold of the

DOI: 10.1097/01.LAB.0000042240.52093.0F

Received September 6, 2002.

This work was supported by Grant CA21246 from the United States Public Health Services (to AEC) and the Leister Knight Endowed Chair (to L-JD). Address reprint requests to: Dr. L. Dong, Departments of Obstetrics \& Gynecology and Biochemistry, Rush-Presbyterian-St. Luke's Medical Center, Chicago, Illinois60612. E-mail: Idong@rush.edu basement membrane, a morphologically distinct structure of the extracellular matrix (Timpl and Brown, 1996; Yurchenco and O'Rear, 1994). Entactin-1 also binds to other extracellular matrix proteins such as fibronectin (Hsieh et al, 1994; Wu et al, 1991), fibrinogen (Wu and Chung, 1991), fibulin-1 (Adam et al, 1997), fibulin-2 (Sasaki et al, 1995), and perlecan (Kvansakul et al, 2001). In addition to these properties, entactin-1 enhances the adhesion of cells (Dong et al, 1995) and promotes the chemotaxis and phagocytosis of neutrophils (Senior et al, 1992). The attachment to cells is mediated by the $\alpha 3 \beta 1$ and $\alpha v \beta 3$ integrin receptors (Dong et al, 1995; Gresham et al, 1996; Wu et al, 1995).

Extensive gene targeting studies on the in vivo role of specific components of the extracellular matrix and the basement membrane have been performed. These experiments have yielded valuable insights into various aspects of embryogenesis and organ development and function (Costell et al, 1999; Hynes, 1994; Miner et al, 1998; Miyagoe et al, 1997; Noakes et al, 1995; Ryan et al, 1999; Smyth et al, 1998). The important cellular functions of entactin-1 encouraged us to explore its role in the organization and function of basement membranes and in the organization and maintenance of the integrity of tissues in vivo. We 
have therefore inactivated the entactin-1 gene by targeting the first exon and promoter region of the gene in mouse embryonic stem (ES) cells. Phenotypic analyses of the entacin-1 null mutants that we have generated reveal the presence of neurologic deficits, which were not reported in a previous study in which entactin-1 gene was targeted at exon 3 (Murshed et al, 2000). In addition, closer examination by electron microscopy showed structural alterations of the basement membranes in selected locations, demonstrating for the first time an in vivo function of entactin-1 in maintaining the structural integrity of the basement membranes. The pathologic implications of the introduced mutation in the entactin-1 gene are discussed.

\section{Results}

\section{Targeted Inactivation of the Functional Locus of Entactin-1 Gene in Mice}

In our first attempt to target the entactin-1 gene, a targeting vector (TV1; not shown) directed to the $5^{\prime}$ end of the gene was used. Homologous recombination took place at one locus of the entactin-1 gene (our unpublished data); however, when transmitted through the germline, this targeted mutation failed to inactivate the expression of entactin-1 in mice (Table 1). Further analyses of yeast artificial chromosome (YAC) clones within and near the entactin-1 gene by Southern blotting and PCR indicated a precise duplication of the target locus (Fig. 2).

A second targeting vector (TV2) was then constructed with the same targeting sequence as in TV1 (Fig. 1A) and introduced into one of the ES cell clones previously targeted by TV1 (clone 9B2, first panel, Fig. $1 \mathrm{~B})$. The rationale is that the probability of targeting to the nonfunctional locus again would be reduced if two consecutively targeted alleles carry separate selection markers. Of 350 clones analyzed, 7 were identified to have undergone an additional homologous recombination event as evidenced by the appearance of a second targeted allele, the 14-kilobase (Kb) Xbal fragment. Two of the TV2-targeted ES cell clones are shown in the first panel of Figure 1B. As a result of the two consecutive targetings, each of the TV2-targeted
ES cell clones carries three distinct $X$ bal bands. They are the 14-Kb TV2-targeted allele with hygro ${ }^{\mathrm{R}}$, the 4.4-Kb wild-type allele, and the 3.6-Kb TV1-targeted allele carrying neo ${ }^{R}$. Notably, even after a second round of targeting, the wild-type allele (4.4-Kb Xbal) was still present; phosphorimaging analysis yielded a ratio of 1:2:1 among the three Xbal bands (Fig. 1B), a clear indication that four apparent copies of the target locus existed, indicating a gene duplication event at the locus.

Clone 2B5 was used to generate mutant mice. F1 mice through germline transmission carried either neo $^{R}$ or hygro ${ }^{R}$ but not both (not shown). Genotyping revealed that all of hygro ${ }^{\mathrm{R}}-\mathrm{F} 2$ mice carried either two or three copies of the wild-type allele (4.4-Kb Xbal) (Fig. 1B, Table 1); approximately three-quarters of the 245 F2 mice examined had one or two copies of the TV2-targeted allele (14-Kb Xbal) (Fig. 1B, Table 1), thus confirming a pattern of Mendelian inheritance (Table 1). Importantly, complete absence of entactin-1 gene expression was observed in mice homozygous for the TV2-targeted allele by the criteria of Western blotting (Fig. 8A), Northern blotting (panel a, Fig. 1C), and RT-PCR detection (panel b, Fig. 1C). In heterozygous individuals, the level of entactin-1 protein expression was about $50 \%$ of that observed in the wild-type group (Fig. 8A).

F2 mice carrying the neo ${ }^{R}$ expressed entactin-1 regardless of their genotypes (not shown). Figure 1C (panel c) shows entactin-1 protein expression of two ES cell lines established from blastocysts homozygous for TV2-targeted (JAT2-91) or TV1-targeted (JAT1-151) alleles. All trans-retinoic acid was used to induce entactin-1 expression (Durkin et al, 1986). Clearly, cells that are homozygous null for the TV2targeted allele failed to produce enactin-1 protein with or without induction by retinoic acid, demonstrating that only the TV2-targeted locus was functionally relevant for entactin-1 gene expression.

\section{Further Evidence of Entactin-1 Gene Duplication}

To obtain further evidence of gene duplication at the target locus, contigs of overlapping mouse YAC

Table 1. Targeting to the Two Distinct Loci of the Entactin-1 Gene

\begin{tabular}{lcccccc}
\hline & \multicolumn{3}{c}{ TV1-targeted mice } & \multicolumn{3}{c}{ TV2-targeted mice } \\
\hline 4.4K:3.6K/14K(Xbal) & $4: 0$ & $3: 1$ & $1: 1$ & $4: 0$ & $3: 1$ & $1: 1$ \\
Genotype & $+/+$ & $+/-$ & $-/-$ & $+/+$ & $+/-$ & $-/-$ \\
Number of F2 & 28 & 41 & 20 & 70 & 120 & 55 \\
Mendelian ratio & $1:$ & $2:$ & 1 & $1:$ & $2:$ & 1 \\
Selection marker & $-/-$ & $\mathrm{NeO}^{\mathrm{R}}+/-$ & $\mathrm{NeO}^{\mathrm{R}}+/+$ & $-/-$ & Hygro $^{\mathrm{R}}+/-$ & Hygro $^{\mathrm{R}}+/+$ \\
Entactin-1 expression & ++ & ++ & ++ & ++ & + & - \\
\hline
\end{tabular}

Mendelian distributions of the TV1- and TV2-targeted alleles are demonstrated. The first row indicates the approximate ratio of wild-type (4.4-Kb Xbal) versus targeted (3.6-Kb Xbal for TV1 or 14-Kb Xbal for TV2) alleles as measured by phosphorimaging. Separate targeting experiments with TV1 (neo ${ }^{\mathrm{R}}$ ) or TV2 (hygro ${ }^{\mathrm{R}}$ ) produced the ES cell clones known as 9B2 and 2B5 (Fig. 1). 2B5 was the result of the second targeting (TV2-mediated) on the ES cell clone 9B2, therefore harboring one additional targeted allele (14-Kb Xbal, Fig. 1). When germline transmitted, the two-targeted alleles (3.6-Kb Xbal from TV1 and 14-Kb Xbal from TV2) in ES cell clone 2B5 were separated, because F1 and F2 individuals were either neo ${ }^{R}$ or hygro ${ }^{R}$ but not both (not shown). TV1- and TV2-targeted alleles represent the two duplicated loci at the $5^{\prime}$ end of the entactin-1 gene. The homozygous null status for each had a totally different impact on entactin-1 gene expression, substantiating the notion that only one of the duplicated loci functionally encodes the entactin- 1 gene in mice. 
A
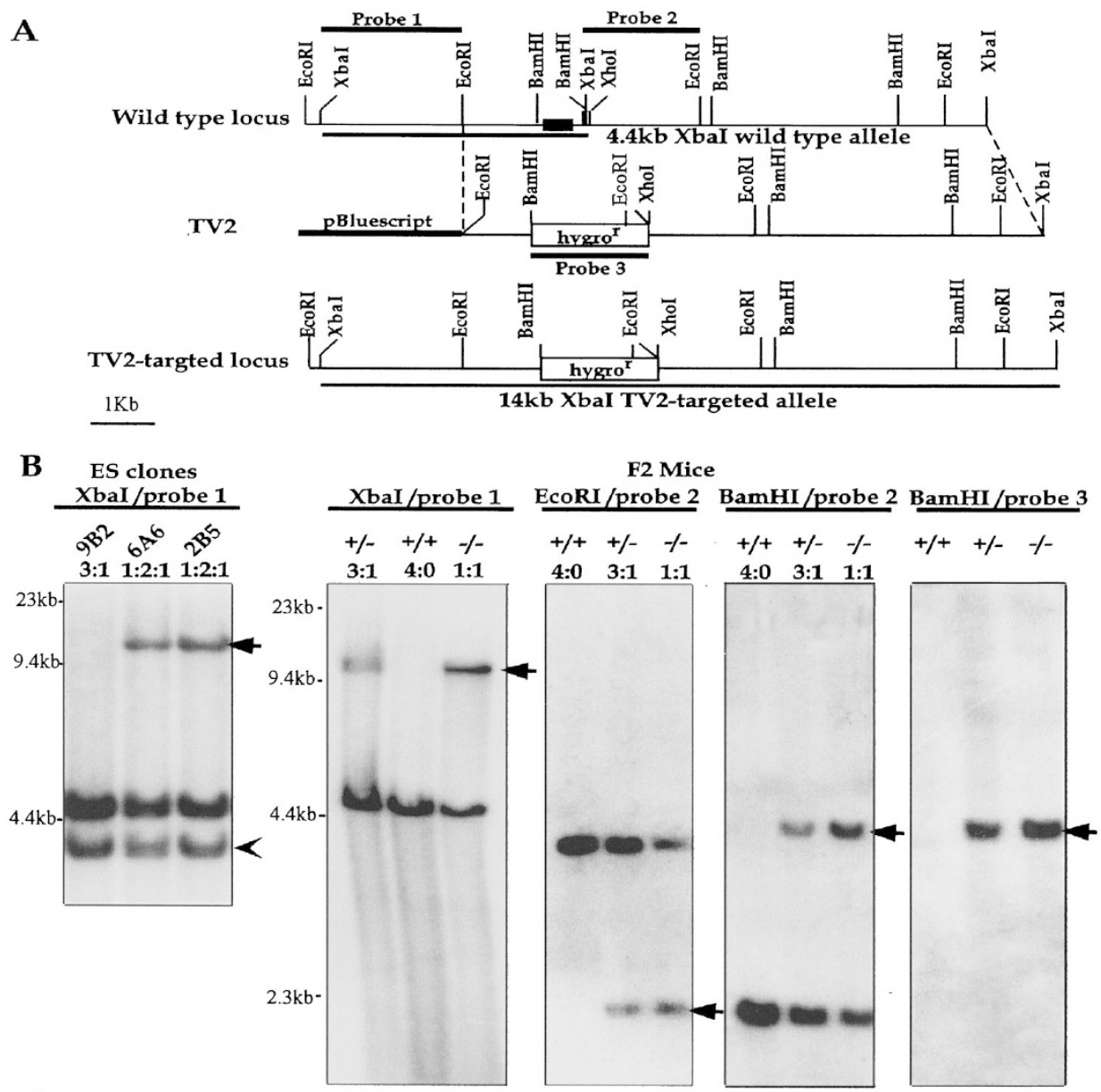

C

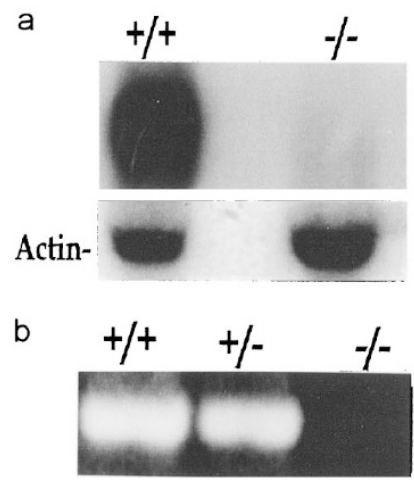

c

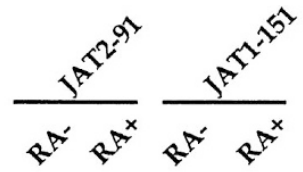

$200 \mathrm{kd}-$

Actir-

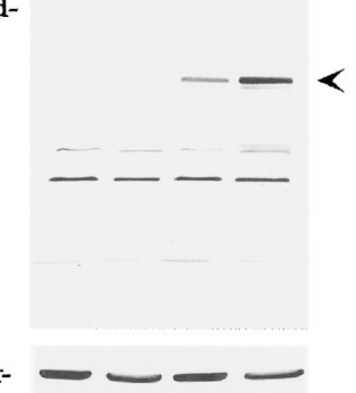

\section{Figure 1.}

Targeted disruption of the functional locus of the entactin-1 gene. A, Maps of the wild-type locus, targeting vector (TV2), and targeted locus. B, Southern blot analyses of genomic DNA from embryonic stem (ES) cell clones and F2 mice. Because 9B2 was the starting cell line in the TV2-mediated targeting, ES cell clones targeted by TV2 (6A6 and 2B5) displayed two targeted alleles, the 3.6-Kb Xbal band (first panel, arrowhead) derived from TV1 targeting and the 14-Kb Xbal band (arrow) from TV2 targeting. The two targeted alleles were separated in the F1 population. F1 mice carrying hygro ${ }^{\mathrm{R}}$ were mated to produce F2. Xbal-digested genomic DNA of F2 mice was hybridized with Probe 1 (external) to confirm targeted-integration at the entactin-1 gene locus (second panel). To further verify the intensity ratio of wild-type to mutant alleles in F2 mice, an internal probe (Probe 2) was used to hybridize genomic DNA digested with EcoRI (third panel) or BamHI (fourth panel). BamHI-digested genomic DNA was also probed with a hygromycin-resistant gene sequence (Probe 3 ) to demonstrate single-copy integration of the targeting vector (fifth panel). Arrows point to the mutant allele from TV2-targeting in each blot. C, Entcatin-1 expression in TV2-targeted mice. Northern blot (a) and RT-PCR (b) detection for entactin-1 gene expression in skeletal muscles. Induction of entactin-1 in ES cells isolated from TV2- or TV1-targeted mouse embryos (c). Two ES cell lines were established from TV1-targeted (JAT1-151) and TV2-targeted (JAT2-91) mice (our unpublished data), respectively. Total cellular proteins were analyzed by Western blotting with the polyclonal antibody against entactin-1. RA+ and RA-, with or without retinoic acid treatment. The arrowhead points to the entactin-1 band. Anti- $\beta$ actin staining (Actin) served as a control for loading. 
A
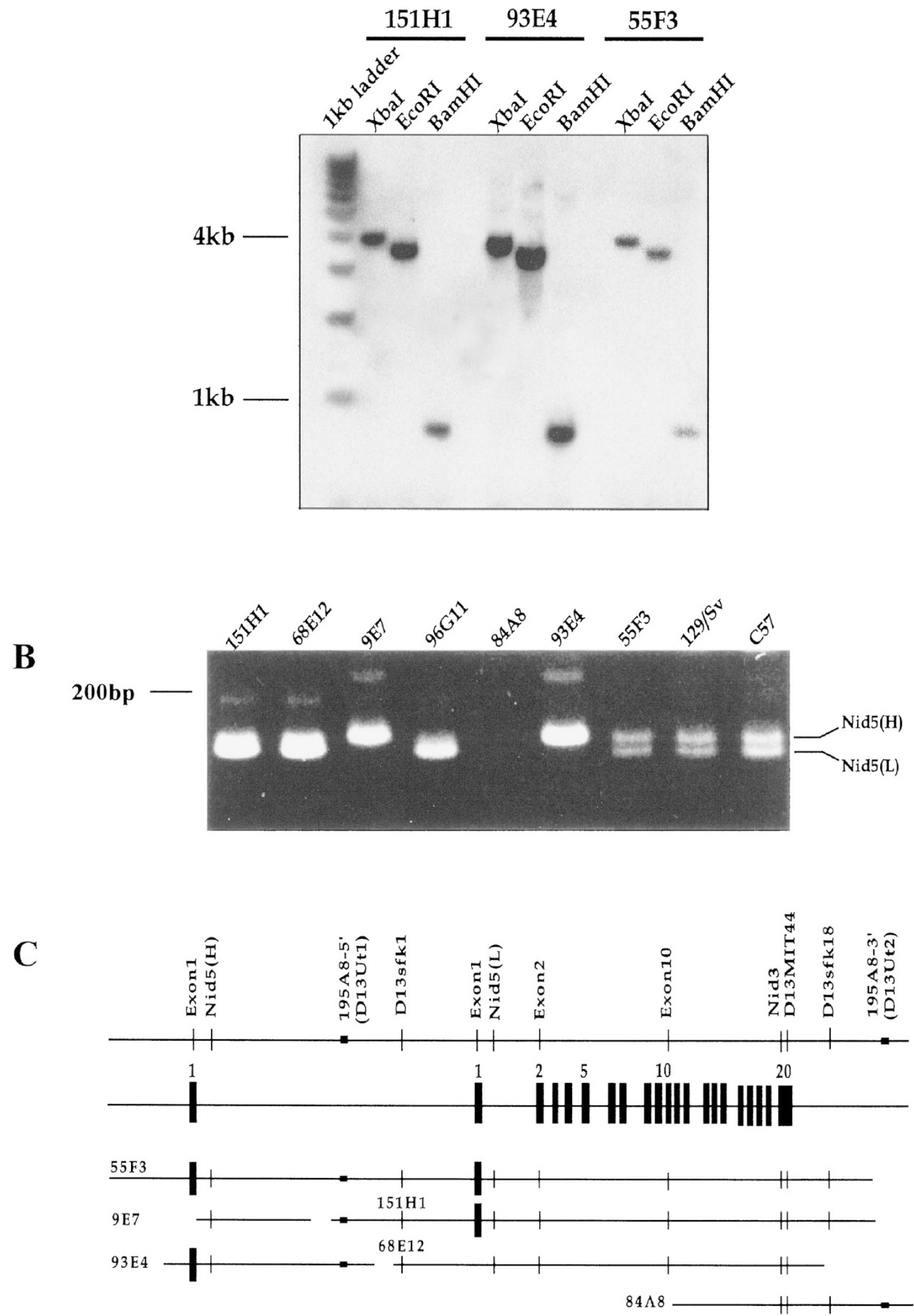

\section{Figure 2.}

Further evidence of entactin-1 gene duplication. A, Southern blot of three overlapping yeast artificial chromosome (YAC) clones at the entactin-1 gene locus. YAC DNA preparations were digested with various restriction enzymes as indicated and probed with a 200-bp probe of exon 1. B, PCR analyses of Nid5 from individual YAC clones and from mouse genomic DNA 129/Sv (ES cell) and C57 (C57BL/6 mouse tissue). PCR products were separated on a nondenaturing glycerol-polyacrylamide gel $(10 \%)$ overnight, and DNA bands were visualized by ethidium bromide staining. Nid5(H) and Nid5(L) are the higher and lower forms of Nid5 PCR products, respectively. C, A refined physical map of the entactin-1 gene, in which duplication of the region of the 5' entactin-1 gene is reflected. Contig of six overlapping YAC clones (ResGen, Huntsville, Alabama) from the region of the entactin-1 gene on mouse chromosome 13 are also shown. 
clones within or near the region of the entactin-1 gene (Perou et al, 1996) were used in genomic mapping by Southern blotting and PCR. Three of the YAC clones (93E4, 151H1, and 53F3) were probed with a 200-bp cDNA from exon 1 of the entactin-1 gene. Clone $151 \mathrm{H} 1$ has been shown previously to contain the entire mouse entactin-1 gene (our unpublished data). However, the first exon of the entactin- 1 gene was found not only in $151 \mathrm{H} 1$ and $55 \mathrm{~F} 3$ but also in the upstream clone 93E4 by Southern blotting (Fig. 2A), demonstrating the existence of a second locus for entactin-1. Importantly, no detectable differences in restriction fragment lengths were observed between the two loci with each of the three restriction enzymes used in genotyping. These data explain why there were four apparent copies of the target, and two copies of a wild-type allele were always detectable in the homozygous null genotype for each of the targeted loci.

A number of well-characterized genetic markers were used in the alignment shown in Figure 2C, including Nid5 (Kingsmore et al, 1996), which marks a region immediately downstream of exon 1 of the entactin-1 gene. As shown in Figure 2B, mixed Nid5 PCR products of a higher $[\mathrm{Nid} 5(\mathrm{H})]$ and a lower [Nid5(L)] band were detected in genomic DNA obtained from 129/Sv mouse ES cells and C57BL/6 animals. The YAC clone 55F3 also gave rise to two products similar to those seen in mouse genomic DNA. Except for clone 84A8, each of the other YAC clones, when used as template, had a single product band that was either Nid5(H) (9E7 and 93E4) or Nid5(L) (151H1, 68E12, and 96G11). Thus, Nid5(H) and Nid5(L) are in separate genomic locations. The existence of two forms of Nid5 marker arranged in cis on a single chromosome has provided additional support for the argument that the entactin-1 gene has a duplicate locus, at least for its $5^{\prime}$ region.

\section{Neurologic Defects in Mice Lacking Entactin-1}

Close observation revealed unusual behavior patterns in the TV2-targeted entactin-1 null mutants. The first abnormality, which occurred sporadically, was observed during grooming. The animals began to groom in the usual manner and then suddenly lost control and initiated involuntary movements that resembled a seizure (Fig. 3, Table 2). The head and upper body began a series of repetitive bowing motions as the animal staggered around on its hind legs. This episode would cease abruptly, with the animal resuming its normal behavior. The second abnormality was observed under the influence of mild carbon dioxide exposure ( $\mathrm{CO}_{2}$ for 5 seconds). The hind legs of the null mutants became rigidly extended in contrast to the heterozygous mutant or wild-type animals, which assumed relaxed postures (Table 2 ). The mutant animals rapidly recovered without any obvious harmful effects. A third behavioral abnormality was observed when animals were removed from their cages by their tails. The animal would distort its body into a twisted posture, with its front legs held closely to its body or it would rigidly extend its hind legs and initiate a flailing movement (Fig. 4, Table 2). Upon release of the animal, its hind legs seemed to be temporarily paralyzed and extended behind its body. In some animals this lasted for several minutes, with the extended leg undergoing tremors. The last two observations of abnormal behavior were not sporadic, rather they occurred in all homozygous mutants. The response of the homozygous null mutant animals to mild carbon dioxide exposure at the time of weaning accurately predicted their genotype (not shown).

\section{Basement Membranes Were Formed in the Absence of Entactin-1}

To evaluate the consequences of removing the entactin-1 gene on the structural integrity of the basement membranes, a variety of tissues were examined by immunohistochemistry. Frozen sections were immunostained for the normal components of basement membranes. In tissues of homozygous null mice, no staining was observed for entactin-1 (Fig. 5); staining for laminin-1 and type IV collagen was normal and revealed the presence of basement membranes in all the tissues examined (not shown). Ultra thin sections were studied by electron microscopy (EM). The sections revealed the presence of basement membranes in all the tissues examined in the homozygous null mice. Further comparison between wild-type and entactin-1-deficient mice showed no apparent differences in a number of tissues, including kidney, skeletal muscles, cardiac muscles, intestine, and the lungs (not shown).

\section{Thinning and Discontinuity of the Basement Membrane in Brain Capillaries}

In contrast to the normal morphology of the basement membranes in most tissues, EM revealed apparent abnormalities in the subendothelial basement membranes in the brains of entactin-1 null mice. The capillaries in the central nervous system have a distinct and complete layer of basement membrane surrounding the endothelial cells as a structural component of the blood-brain barrier (Schlosshauer, 1993). In wild-type mice, this basement membrane is a continuous and homogeneous layer of electron dense material, 40 to $60 \mu \mathrm{m}$ in width, that separates the endothelium from astrocytes, as illustrated for typical sections in Figure 6. In contrast, the capillary basement membranes in brains of mutant littermates were less homogeneous. Sampling through the cerebral cortex showed apparent thinning of the basement membrane in cross-sections of the capillaries (Fig. $6 \mathrm{~A})$, whereas in others the basal lamina was completely absent (Fig. 6B). In some cases, the absence of basement membrane resulted in the appearance of swollen endothelial cells (Fig. 6B). In sections where the mutant basement membrane appeared normal at low magnification (less than $\times 15,000$ ) (not shown), closer examination at higher magnification (greater than $\times 50,000$ ) revealed an altered staining pattern for 

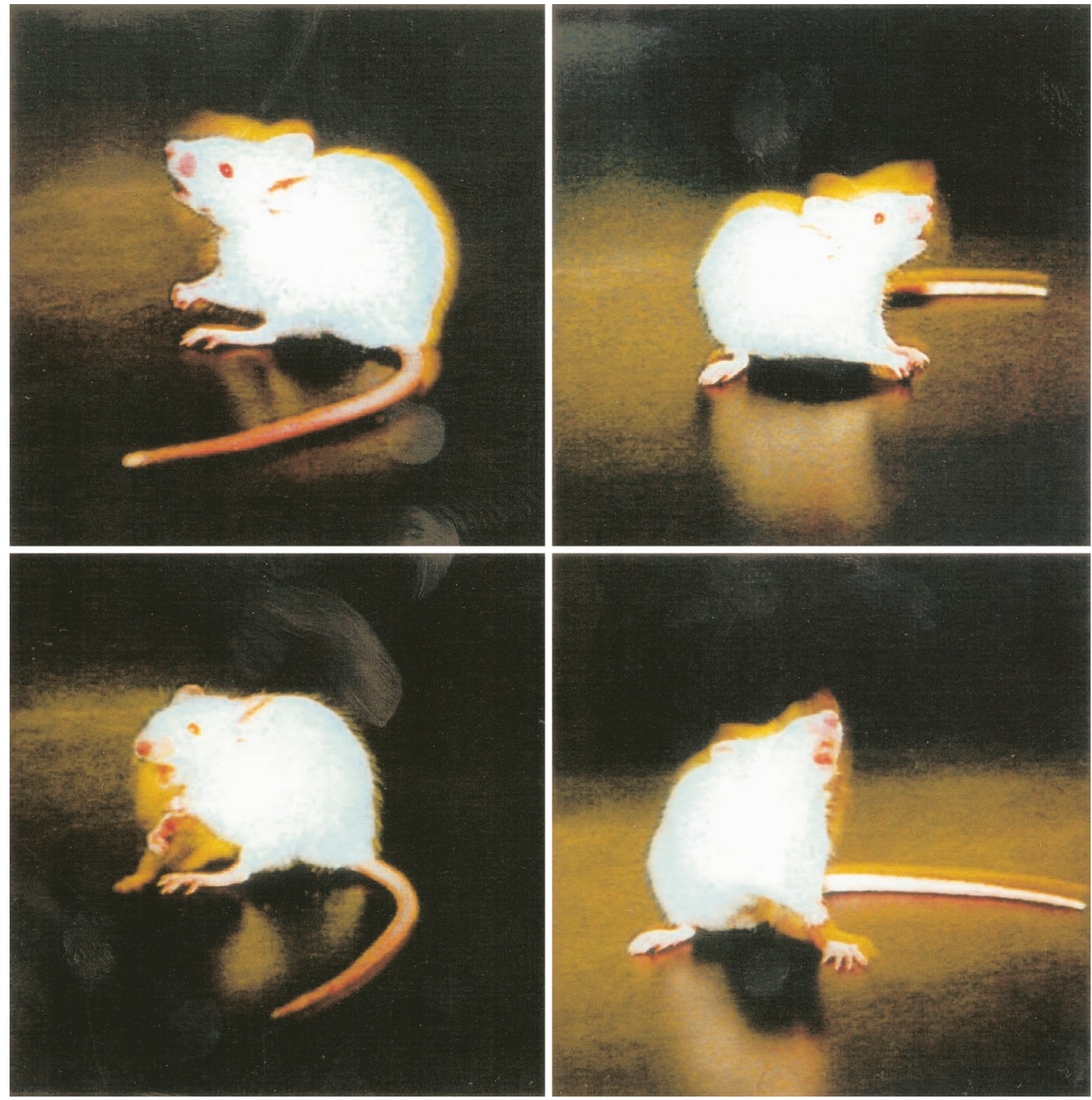

\section{Figure 3.}

Photographs of entactin-1 null mice undergoing spontaneous seizure. Serial photographs of an entactin-1 null mouse taken during an episode. Details are described in "Results."

the basal lamina materials (Fig. 6C). For example, the lamina densa of the basement membranes of wildtype mice appeared as a fine network of irregular cord-like structures, whereas in the mutants, it stained as compact aggregates of ribbon-like structure with a repeating pattern of "double tracks."

\section{Abnormal Interface of Lens Capsule with the Basal Surface of Elongating Fibers}

The morphology of the lens capsule and associated lens cells was examined by EM. These studies showed that in wild-type lenses, the basal surfaces of the elongating fiber cells were in close and continuous contact with the homogeneous basal lamina of the lens capsule. In sharp contrast, in the lens from a 7-week-old entactin-1 null mouse, the border between elongating fiber cells and the posterior lens capsule was highly irregular (Fig. 7). Numerous examples of elongating fiber basal membrane were observed protruding into the basal lamina of the posterior lens capsule.

\section{Entactin-2 Expression in Tissues with Altered Structure of Basement Membranes}

To explore the potential compensational roles of entactin-2 in entacin-1 null mice, tissues in which abnormal structures of the basement membrane have been observed were studied for entactin-2 expression 
Table 2. Neurologic Phenotypes

\begin{tabular}{|c|c|c|c|}
\hline & \multicolumn{3}{|c|}{ Entactin-1 genotype } \\
\hline & \multirow[t]{3}{*}{$+/+$} & \multicolumn{2}{|c|}{$-1-$} \\
\hline & & \multicolumn{2}{|c|}{$\begin{array}{c}\text { From seizure } \\
\text { parents }\end{array}$} \\
\hline & & No & Yes \\
\hline \multicolumn{4}{|l|}{$\begin{array}{l}\text { Loss of control of hind } \\
\text { legs (by tail-lifting } \\
\text { or } \mathrm{CO}_{2} \text { treatment) }\end{array}$} \\
\hline Positive response & 0 & 66 & 119 \\
\hline Total examined & 104 & 66 & 119 \\
\hline Percentage & 0 & 100 & 100 \\
\hline \multicolumn{4}{|l|}{$\begin{array}{l}\text { Seizure-like movements } \\
\text { (spontaneous) }\end{array}$} \\
\hline Positive response & 0 & 21 & 71 \\
\hline Total examined & 104 & 66 & 119 \\
\hline Percentage & 0 & 32 & 60 \\
\hline
\end{tabular}

For phenotype of seizure-like movements, mice from each genotype group were observed during the day directly in their tubs with the lid off for 60 minutes without any applied stimuli. Mice that had at least one episode of seizure during this period were counted as positive. For loss of muscle control in hind legs, observations were made after lifting by the tail or with $\mathrm{CO}_{2}$ exposure for 5 seconds in a closed glass chamber. Animals examined were 4 to 12 weeks old

by Western blotting. As shown in Figure 8, brain and lens had a relatively lower level of entactin-2 expression as compared with skeletal and cardiac muscles. In homozygous mutants, the level of entactin-2 protein expression is apparently up-regulated in the skeletal muscle and somewhat up-regulated in the cardiac muscle. No obvious up-regulation of entactin-2 protein synthesis has been detected in either brain or lens of the homozygous null mice.

\section{Discussion}

Targeted mutagenesis to the $5^{\prime}$ end of the entactin-1 gene in the mouse has genetically revealed a duplication event at this locus. The genetic evidence was further supported by results from physical mapping. This duplication event, however, may not have involved downstream exons other than exon 1, because no sequence-tagged site of either exon 2 or exon 10 of the entactin-1 gene was detected in the YAC clones from the Nid5H locus by PCR (our unpublished data). Sequence analyses revealed several minor differences within exon 1 as well in the promoter region between the two loci (our unpublished data). Further sequencing of the reverse-transcribed products from the entactin-1 transcripts confirms that the endogenous transcripts of entactin-1 contain only the exon 1 sequence of the Nid5L locus (our unpublished data). Thus, it seems that Nid5L is functionally relevant and was targeted by TV2 in our entactin-1 null mice. Further studies on the transcriptional activation activities of the promoter region from the two loci are currently under investigation to better understand the nature of the duplication at the 5 ' end of the entacin- 1 gene.

No detectable differences in restriction fragment length were detected between the two loci of the entactin-1 gene with the three restriction enzymes used in Southern genotyping, substantiating the observation that four apparent copies for the target locus exist in the mouse genome. In an attempt to provide a better genotyping strategy, a $\lambda$ phage clone of $12 \mathrm{~Kb}$ corresponding to the Nid5H locus of the entactin-1 gene was further mapped for restriction digestion sites with additional enzymes by partial digestion and endspecific probe labeling (our unpublished data). Comparison with a previously characterized clone from the Nid5L locus (Durkin et al, 1995) revealed no variations in restriction digestion pattern (our unpublished data). A disadvantage of having two target loci that are closely related in sequence could be that the functionally relevant locus can be missed in homologous recombination-mediated targeting process, as appears to have occurred in our study. Another technical challenge from having four apparent copies, instead of two, of the target sequence was that all the genotyping had to be based on intensity ratios between the targeted and wild-type alleles.

The TV-2-targeted entactin-1 null animals that were generated in our studies were viable, bore normalsized litters, and appeared to be normal in overall physical aspects, results that were similar to those described in an earlier report by Murshed et al (2000). The neurologic symptoms, which were not described in the previous report, are consistent and have persisted through generations, even after being backcrossed into a C57/BL6 background (not shown), thus linking entactin-1 to the mechanisms of neuromuscular control.

The sporadic seizure-like movements are reminiscent of those observed in Parkinson's patients and might suggest a deficiency in the neurotransmission pathways in the basal ganglia. However, there is lack of convincing evidence showing neuronal degradation in regions of striatum and substantia nigra of mutant brains (not shown), and tyrosine hydroxylase levels (Haavik and Toska, 1998) were found comparable to those in wild-type animals by immunostaining (not shown). Neuromuscular junctions were also found to be intact in mutant muscles as indicated by $\alpha$-acetylcholine receptor staining (not shown). At present, the pathologic basis for this behavior abnormality found in the entactin-1 null animals is not understood. A potential link could be the modification of the blood-brain barrier in the cortex as a result of changes in the underlying basement membrane, a notion that is supported by the observation of endothelial cell swelling in the areas lacking basement membrane. We speculate that both endothelial and astrocytic populations on each side of the defective subendothelial basement membrane were functionally impacted, which may serve as the pathologic basis for the spontaneous seizure in entactin-1 null mice for the following reasons. Glucose and other nutrients pass 


$$
+1+
$$
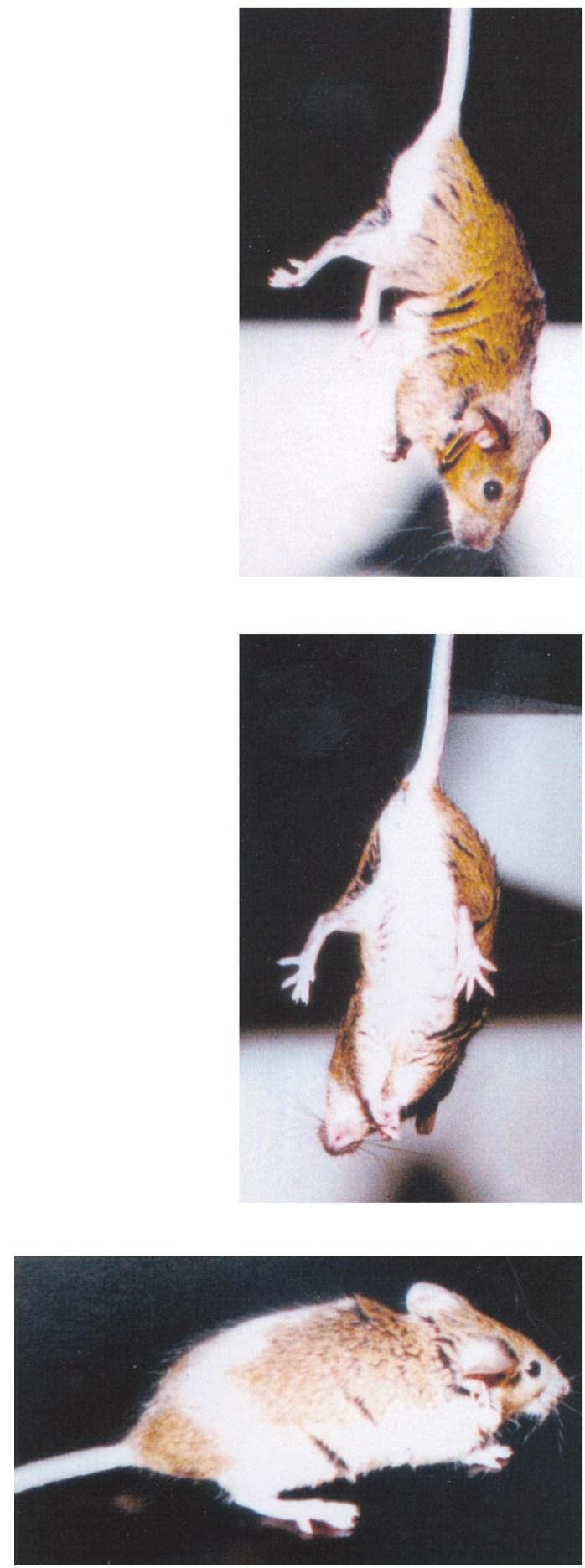

$-1-$

lift

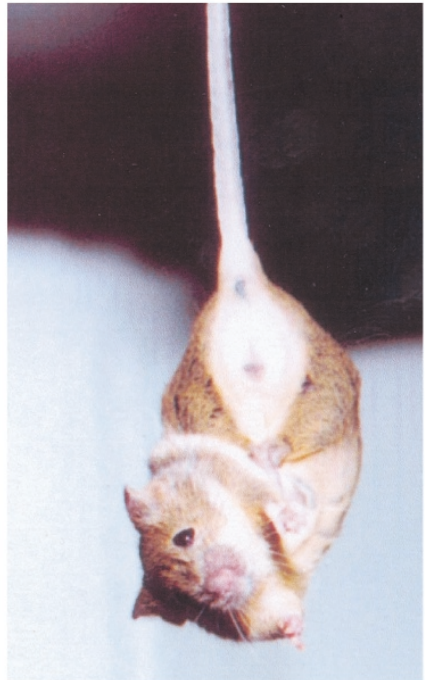

hold
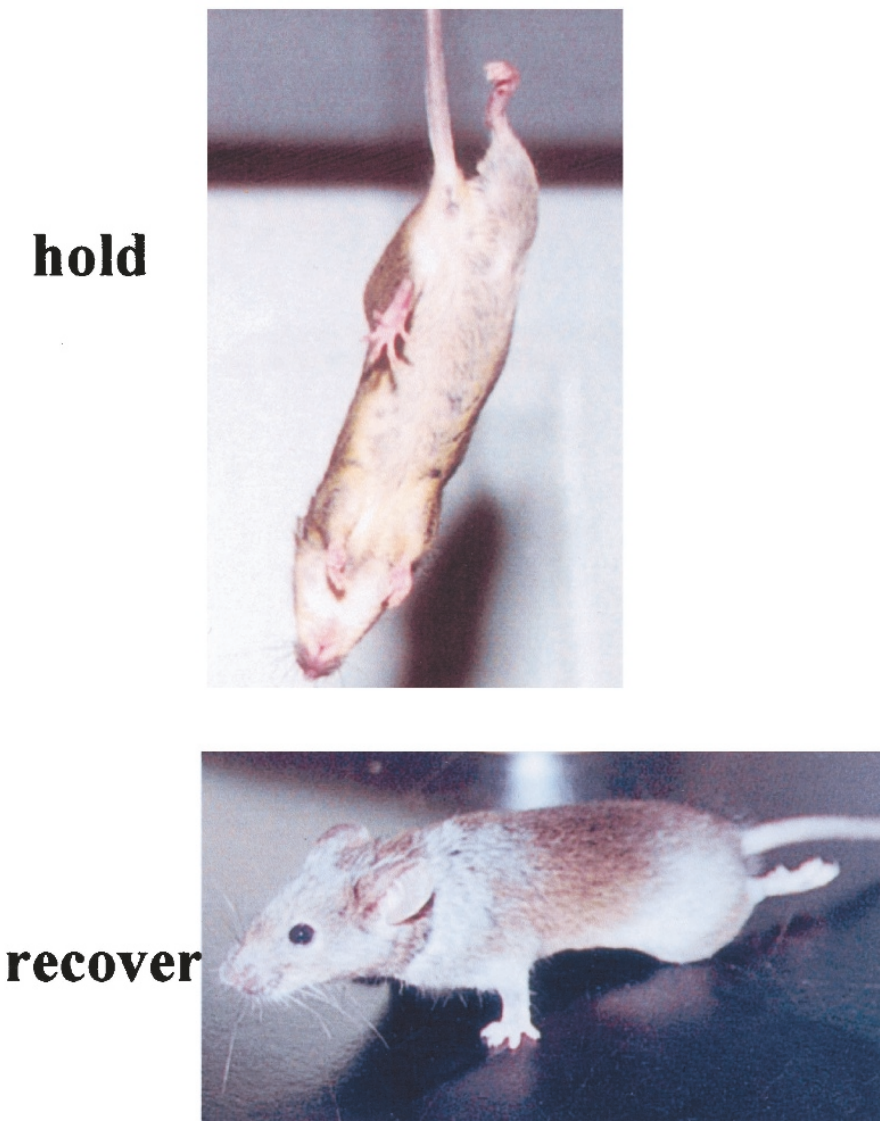

\section{Figure 4.}

Comparison of the response of a wild-type and mutant mouse to suspension by the tail. Details are described in "Results."

through the blood-brain barrier through active transporters on the endothelial cell membrane (Pardridge, 1991; Rayner, 1996; Vannucci et al, 1998). Decreased glucose uptake and hypometabolism have been observed in seizure foci (Janigro, 1999). Also, astrocytes and endothelial cells play important roles in regulating intercellular levels of potassium and other ions that are important in brain electrophysiology (MacVicar, 1989; O’Donnell et al, 1995; Walz, 2000; White et al, 1992). Lost functions of astrocytes have also been linked to epileptic seizure (Heinemann et al, 1999). Decreased glucose uptake and diminished ion homeostasis may induce the seizure-like movements observed in mutant animals. 


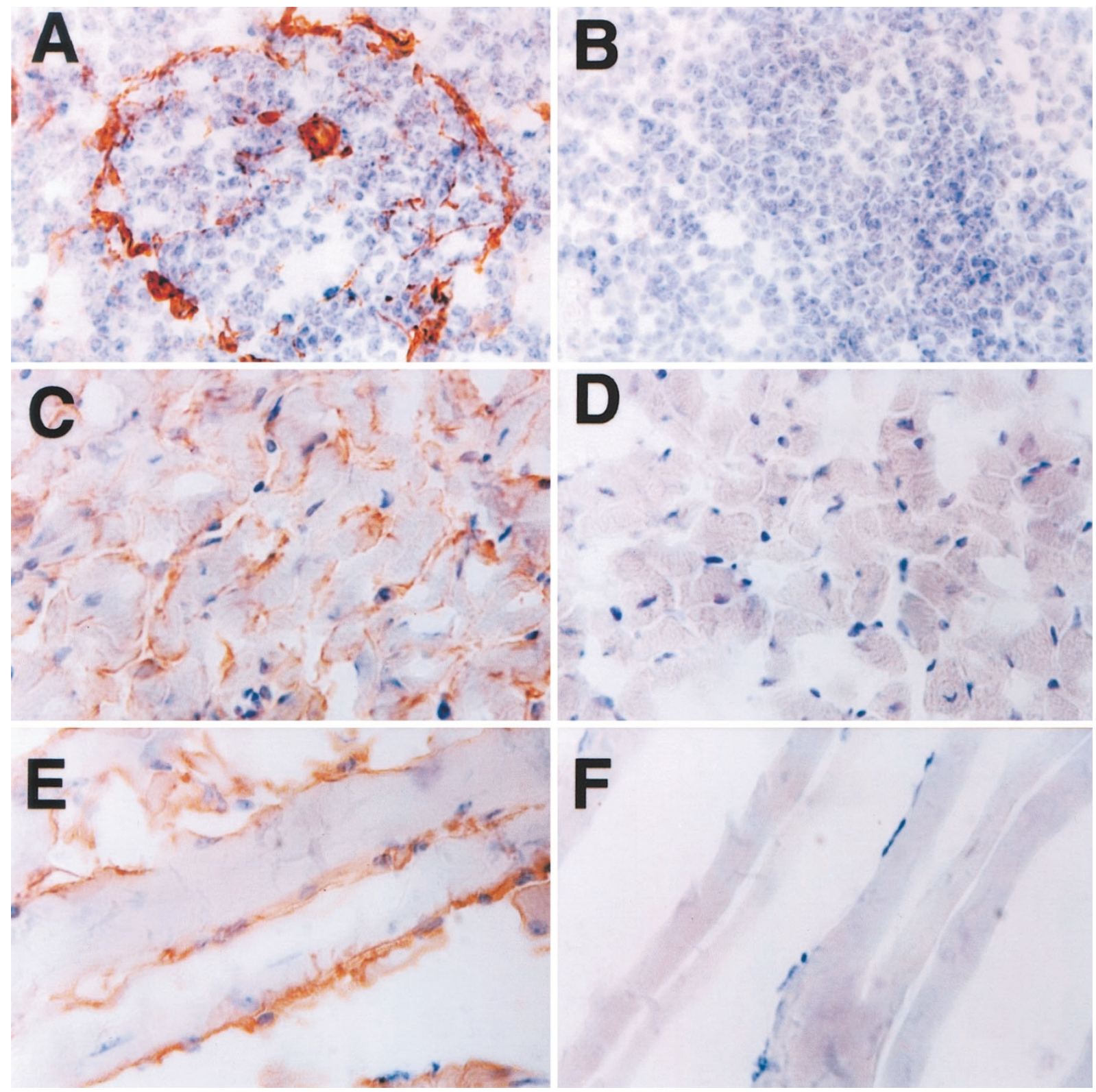

Figure 5.

Immunoperoxidase staining for entactin-1 on frozen sections of mouse tissues. $A$ and $B$, spleen; $C$ and $D$, cardiac muscle; and $E$ and $F$, skeletal muscle. A, C, and E are from wild-type mice; $B, D$, and $F$ are from homozygous mutant mice.

Loss of muscle control in the hind legs was also observed in entactin-1 null mutants either under the influence of $\mathrm{CO}_{2}$ treatment or by tail-lifting (Fig. 4 and Table 2). The frequency of the seizure episode did not increase either by tail-lifting or $\mathrm{CO}_{2}$ treatment (not shown); therefore, it is not known currently if there is a common pathologic basis for all the observed neurologic abnormalities. However, the entactin-1 mutation was sufficient for acquiring the abnormality in hind leg muscle control (100\% penetration, Table 2$)$, whereas an additional genetic modifier(s) seems to be involved in the seizure-like phenotype, because inbreeding among the mice that had seizures led to an increase in apparent penetration (Table 2). A recent study has demonstrated that entactin-1 plays an essential role in neuronal guidance in C. elegans (Kim and Wadsworth,
2000). Entactin-1 could potentially assume a similar role in mammals. Although the molecular mechanism of the neurologic deficit is not known, these transgenic animals should provide a model for further exploration.

Murshed et al (2000) reported no changes in the structure of the basement membranes in mice lacking entactin-1. In our study, extensive examination by EM on a variety of tissues revealed alterations in the morphology of basement membranes in selected locations. In brain capillaries of entactin- 1 null mice, the basement membrane ultrastructurally differs from that in wild-type animals (Fig. 6). Although the molecular composition remains to be elucidated, the abnormal morphology observed at high magnification suggested a structural alteration. Clearly, the degree of 


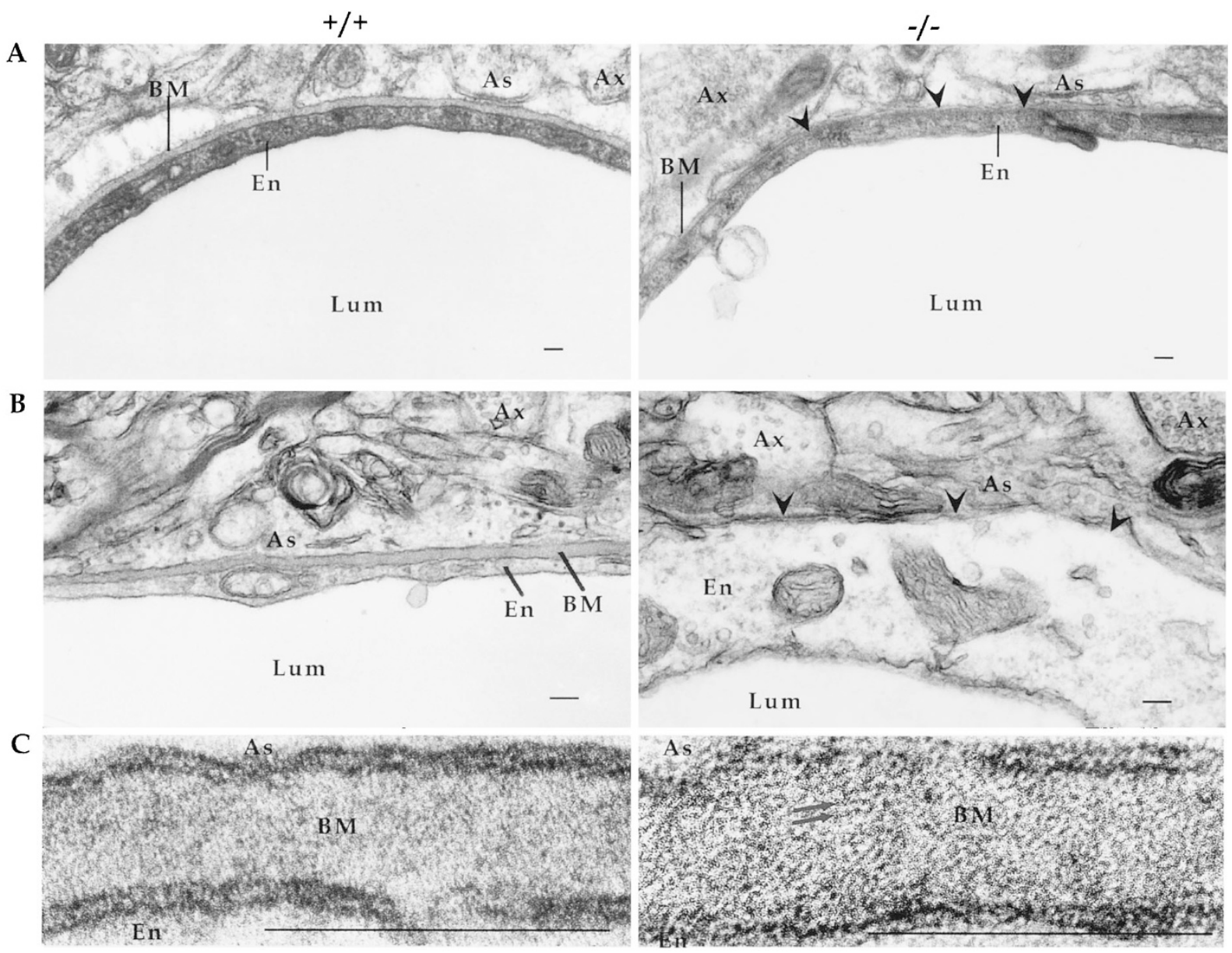

Figure 6 .

Transmission electron micrographs of capillaries in the cerebral cortex of the brains from 18-day-old wild-type $(+/+)$ and entactin-1 null $(-/-)$ mice. A, A continuous and homogeneous layer of basement membrane $(B M)$ is seen between the endothelial cells $(E n)$ and astrocytes $(A s)$ in the cross-section of a capillary from the wild-type brain. In a mutant littermate, a section from an equivalent location within the cortex revealed that the basement membrane was less homogeneous in thickness, with significant thinning in several locations (arrowheads). B, A cross-section of a capillary from wild-type brain again showed an intact and distinct basement membrane. In a mutant capillary from an equivalent location, the basement membrane was completely missing from the interface of endothelium and astrocytes (arrowheads). The endothelial cell showed apparent signs of swelling. C, The ultrastructure of basement membranes from wild-type and entactin-1 null brain capillaries were compared at a much higher magnification. Lum = lumen of capillaries; $A x=$ axons. Bars, $100 \mathrm{~nm}$.

the observable structural abnormality varied at different locations. There were areas where the basement membrane was thin and others where a complete absence of basal lamina material was observed. In extreme cases, endothelial cells became swollen, presumably because of the absence of an intact basement membrane. These results suggest that subendothelial basement membrane was produced in entactin-1 null brains. We speculate that the defects developed at locations where there was additional mechanical, biochemical, or developmental stress. Analogous results were reported in perlecan knockout mice. Mice lacking perlecan had incomplete basement membranes on the brain surface, and the disruptions were observed only in the polar areas of the brain vesicles, where the basement membrane was exposed to increased vesicular pressure (Costell et al, 1999).

EM examination revealed a striking histologic change at the capsule-fiber interface of the lens in the absence of entactin-1 (Fig. 7). The lens is a unique stratified epithelium that originates as an inverted vesicle initially composed of cuboidal epithelial cells. As fiber elongation occurs, the apical membranes of developing fibers interface with the apical membrane of lens epithelial cells, while the basal membranes of these same fibers interface with the posterior lens capsule. The former may involve cell-cell interaction, whereas the latter is governed by cell-extracellular matrix interactions (Menko et al, 1998). Therefore, specific modification of cellular shape and migratory pathway of elongating lens fibers is elementary to normal crystalline lens development (Kuszak et al, 1996). As the basal membranes of elongating fibers became entangled into the posterior lens capsule of entactin-1 null mutant lenses (Fig. 7), elongating fibers might not have been able to either recognize the proper migratory signal or correctly detach when they normally do (Kuszak et al, 1996). Therefore, defective cell-extracellular matrix interactions are implied in this phenotype. Entactin-1 has two separate cell binding sites; each recognizes a different integrin receptor on 
$+/+$

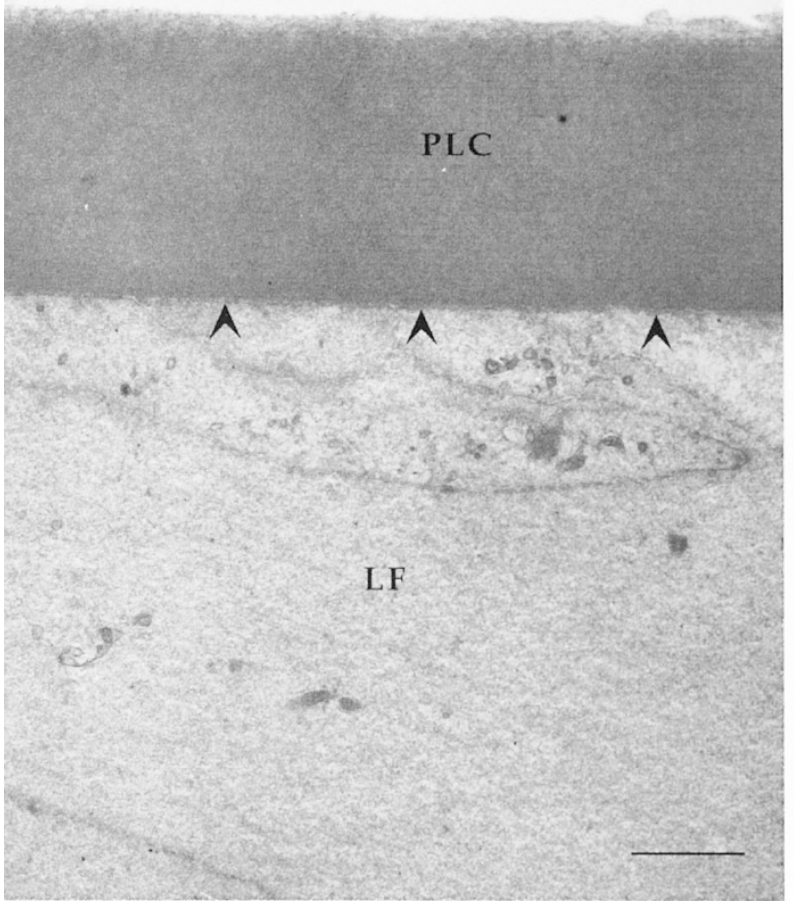

$-1-$

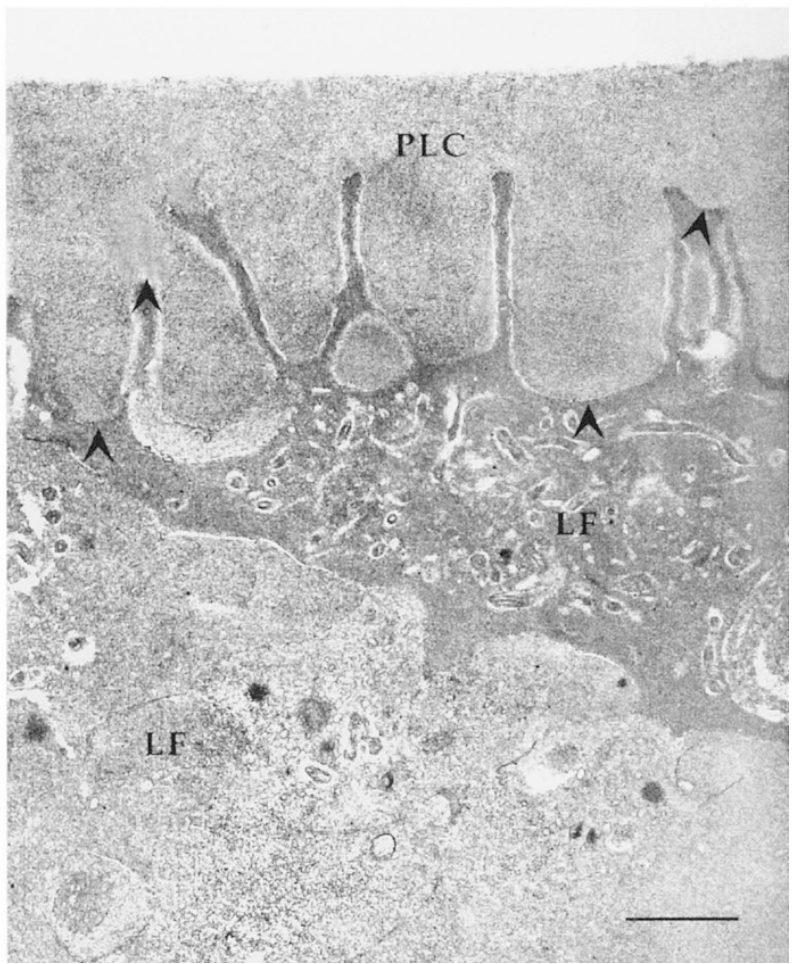

\section{Figure 7.}

Transmission electron micrographs of capsule-cell interface at the posterior portion of lenses from 7-week-old wild-type $(+/+)$ and entactin-1 null $(-/-)$ mice. The posterior lens capsule $(P L C)$ of the wild-type mouse appeared as a filamentous layer of darkly stained basal lamina-like material. The interface with the basal surface of lens fiber cells (LF) was smooth (arrowheads). In the mutant littermate, the posterior lens capsule stained lighter and lacked the filamentous appearance. In addition, the capsule-cell interface (arrowheads) appeared highly irregular and the basement membrane was invaded by the projections from lens fiber cells. Bars, $1 \mu \mathrm{m}$.

the cell surface (Dong et al, 1995). Expression of entactin-1 and laminin genes in lens epithelium of developing mouse embryos peaks at the onset of lens vesicle separation from ectoderm around E11.5 (Dong and Chung, 1991). In SPARC-knockout mice, similar morphologic changes have been described, which preceded cataract formation (Norose et al, 2000). In entactin-1 null mice, no cataract lenses have been found. However, initial examination of the sutures
(Kuszak et al, 1991) from entactin knockout mice has shown that at posterior sutures were not formed (our unpublished data), indicating that fiber cells were not properly organized. Thus, our entactin-1 knockout mice could be used as a model system to further explore the role of the lens capsule in cellular organization of the crystalline lens. In addition, the lens capsule stained lighter and has apparently lost a normal filamentous appearance (Kuszak et al, 1996) in

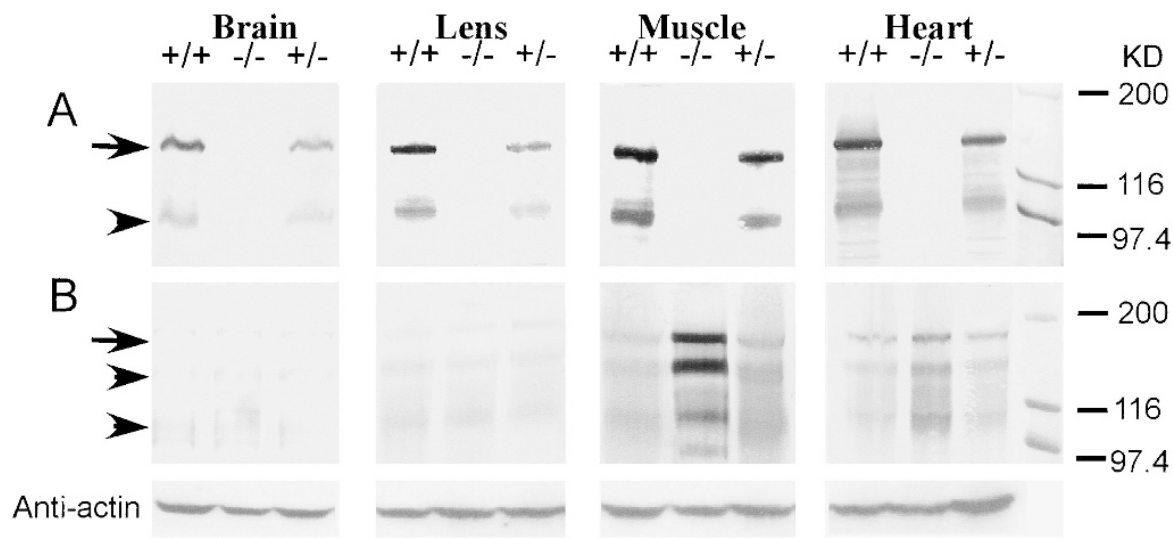

Figure 8.

Western blot detection of entactin-1 and entactin-2 in tissues of adult mice. A, Anti-entactin-1; B, Anti-entactin-2. Arrowheads point to the full-length protein, and arrows indicate major fragments. Anti- $\beta$ actin staining served as a control for loading. 
homozygous mutant lens, an observation substantiating an in vivo structural role of entactin-1 in the basement membrane.

The importance of entactin-1 in the function of basement membranes was implied from its broad distribution in tissues and from its binding properties to extracellular matrix molecules such as laminin, collagen IV, fibronectin, perlecan, and fibulin. Models of basement membrane structure have assigned a major role to entactin-1 in linking the laminin and collagen IV networks. However, entactin-1 null mutation in the mouse has resulted in a rather limited and mild phenotype. A partial explanation for this anomaly is the recent discovery of a mammalian homolog, entactin-2, from mouse and human sources (Kimura et al, 1998; Kohfeldt et al, 1998). Although entactin-2 has only approximately $20 \%$ sequence identity with entactin-1, the macromolecular binding properties and domain organization of entactin-2 were similar but not identical to those of entactin-1. Furthermore, both molecules have similar tissue distribution in the mouse. The apparent normal phenotype of the entactin-1 null mutant mice could, therefore, be a result of the presence of entactin-2. An earlier onset of entactin-2 expression was observed in entactin-1 null embryos (not shown); and in adult skeletal and heart muscles, entactin-2 protein levels were shown to be elevated by immunostaining (Murshed et al, 2000) and Western blotting (Fig. 8B). Furthermore, in the brain and lens, where the basement membrane displayed altered structures in homozygous mutants, the intrinsic level of entactin-2 seems to be lower compared with other tissues in wild-type mice and no obvious up-regulation was observed in homozygous mutant mice by Western blotting (Fig. 8B). It seems that there are selective differences in the abundance and regulation of the entactin-2 gene among different tissues, which may partially explain the observed tissuespecific distribution of the entactin-1-knockout phenotype.

\section{Materials and Methods}

\section{Generation of Entactin-1 Mutant Mice}

Genomic clones of entactin-1 were isolated from a 129/Sv genomic library in the Fix II vector (Stratagene, La Jolla, California). This library was screened with a 0.8-Kb entactin genomic fragment containing the first exon and flanking intron sequences (Durkin et al, 1995). One of the clones isolated (designated as 129/SvEG-1) was used for the construction of two targeting vectors, TV1 (not shown) and TV2 (Fig. 1A). An 8.2-Kb EcoRI-Xbal fragment of 129/SvEG-1 was subcloned, and the $\mathrm{PGKneo}^{\mathrm{R}}$ or $\mathrm{PGKhygro}^{\mathrm{R}}$ cassette was inserted between the first $\mathrm{BamHI}$ site from the $5^{\prime}$ end and a unique Xhol site to form TV1 and TV2, respectively. This insertion resulted in the deletion of translation initiation sequences, exon 1, and part of the promoter region of the entactin-1 gene (Durkin et al, 1995).

G.K.129 mouse ES cells (a gift of Dr. S. Gendler, Mayo Clinic, Scottsdale, New York) were grown under standard conditions on STO cell feeder layers in the presence of LIF. The targeting plasmid DNA was linearized by digestion overnight with Notl and introduced into the ES cells by electroporation under optimized conditions with a Gene Pulser (BioRad, Hercules, California).

First-round targeting with TV1 generated targeted clones that were neo resistant (not shown). One of the clones, 9B2, was microinjected into recipient embryos, and mice homozygous for the targeted mutation synthesized entactin-1 mRNA and protein regardless (not shown). Second-round targeting with TV2 was therefore conducted with ES cells from clone 9B2 (Fig. 1B). Clones resistant to both hygromycin and neomycin were isolated and screened for homologous recombination by PCR (not shown) and Southern blotting (Fig. 1B). TV2-targeted ES cell clones were identified, and clone 2B5 injected into C57BL/6 blastocysts to generate chimeric animals as described (Noakes et al, 1995). Germline transmission was determined by mating chimeric males with C57BL/6 females. Heterozygous animals were crossed to obtain homozygous null animals. For genotyping, tail biopsies $(1 \mathrm{~cm})$ were obtained from mice and placed in $600 \mu \mathrm{l}$ of tail-digestion buffer. The DNA samples prepared were subjected to Southern blot analyses as shown in Figure 1. Phosphorimaging was performed to quantitatively measure copy numbers of identifiable alleles with the software Image Reader V1.8E (Fuji Photo Film Co., Japan).

\section{Immunohistochemistry}

Tissues were quick frozen in Tissue-Tek OCT Compound (Miles Inc., Elkhart, Indiana) for immunohistochemistry. Sections were stained with rabbit polyclonal antibodies against mouse entactin-1, laminin, and type IV collagen (Hsieh et al, 1994). Immunoreactions were visualized in the sections with a VectaStain ABC kit (Vector Laboratories, Burlingame, California).

\section{Western Blot Analyses for Entactin-1 and Entactin-2 Expression}

To obtain proteins, $50 \mathrm{mg}$ of each wet tissue was homogenized in $0.5 \mathrm{ml}$ of the extraction buffer $(10 \mathrm{~mm}$ Tris-HCL [pH 7.8], 50 mm EDTA, 100 mм NaCl, 1\% Triton X-100, $10 \mathrm{ng}$ of leupeptin/ml, $1 \mathrm{ng}$ of pepstain/ $\mathrm{ml}, 1 \mathrm{~mm}$ phenylmethysulfonyl fluoride). After centrifugation, the supernatants were measured for protein by $\mathrm{OD}$, and an equal volume of the $2 \times$ SDS sample buffer was added. Aliquots of $50 \mu \mathrm{g}$ of protein from each tissue were separated by SDS-PAGE on $7.5 \%$ gels under reducing conditions and blotted onto polyvinylidene difluoride membranes as described (Laemmli, 1970). After transferring, the polyvinylidene difluoride membranes were blocked overnight at $4^{\circ} \mathrm{C}$ in $5 \%$ skimmed milk powder diluted in TBST (10 mM Tris [pH 8.0], $150 \mathrm{~mm} \mathrm{NaCl}$, and $0.1 \%$ Tween-20) and incubated with polyclonal rabbit serum either to entactin-1 (Hsieh et al, 1994) (1:5000 dilution) or entactin-2 (Chung et al, unpublished) (1:2000 dilution). As a 
control for protein loading, a monoclonal antibody against $\beta$-actin (Sigma, St. Louis, Missouri) was used on a separate blot obtained from the same gel.

\section{RNA Analyses}

RNA preparations from postnatal tissues or individual embryos (Ultraspec RNA isolation system; Biotecx Laboratories Inc., Houston, Texas) were subjected to Northern blotting or RT-PCR analyses as previously described (Reing et al, 1992) to detect entactin-1 message RNA. The forward primer for entactin-1 was 5'-AGCTTCTATGATCGTACGGACATCAC-3' and the reverse primer was 5'GTAAAGAACTGTAGACCATCTTCAGG-3'.

\section{$E M$}

For EM, mice were perfusion fixed with $2.5 \%$ glutaraldehyde in $0.1 \mathrm{M}$ phosphate buffer ( $\mathrm{PH} 7.4)$. Various organs were then dissected out and placed into the same fixative for a period of 12 to 24 hours at $4^{\circ} \mathrm{C}$. Lenses were taken from mice that were not perfusion fixed. Instead, they were fixed by being immersed into a fixative containing $2.5 \%$ glutaraldehyde in $0.07 \mathrm{M}$ sodium cacodylate buffer at $\mathrm{pH} 7.2$ for 24 to 48 hours at room temperature. After daily changes of fixative, the tissues were washed by repeated buffer rinses to remove residues of fixative. Tissues were then postfixed in $1 \%$ aqueous $\mathrm{OsO}_{4}$, washed in cacodylate buffer, and dehydrated through a graded ethanol series to propylene oxide. Tissues were infiltrated and flat embedded in epoxy resin. Thin sections were cut at $60 \mathrm{~nm}$, stained with uranyl acetate and lead citrate, and then examined on a JEOL JEM-1200EX transmission electron microscope (JEOL USA, Peabody, Massachusetts) at $60 \mathrm{kV}$.

\section{References}

Adam S, Gohring W, Wiedemann H, Chu ML, Timpl R, and Kostka $G$ (1997). Binding of fibulin-1 to nidogen depends on its C-terminal globular domain and a specific array of calcium-binding epidermal growth factor-like (EG) modules. J Mol Biol 272:226-236.

Costell M, Gustafsson E, Aszodi A, Morgelin M, Bloch W, Hunziker E, Addicks K, Timpl R, and Fassler R (1999). Perlecan maintains the integrity of cartilage and some basement membranes. J Cell Biol 147:1109-1122.

Dong LJ and Chung AE (1991). The expression of the genes for entactin, laminin A, laminin B1 and laminin B2 in murine lens morphogenesis and eye development. Differentiation 48:157-172.

Dong LJ, Hsieh JC, and Chung AE (1995). Two distinct cell attachment sites in entactin are revealed by amino acid substitutions and deletion of the RGD sequence in the cysteine-rich epidermal growth factor repeat 2. J Biol Chem 270:15838-15843.

Durkin ME, Chakravarti S, Bartos BB, Liu SH, Friedman RL, and Chung $A E$ (1988). Amino acid sequence and domain structure of entactin: Homology with epidermal growth factor precursor and low density lipoprotein receptor. J Cell Biol 107:2749-2756.
Durkin ME, Philips SL, and Chung AE (1986). Control of laminin synthesis during differentiation of $\mathrm{F9}$ embryonal carcinoma cells: A study using cDNA clones complementary to the mRNA species for the A, B1 and B2 subunits. Differentiation 32(3):260-266.

Durkin ME, Wewer UM, and Chung AE (1995). Exon organization of the mouse entactin gene corresponds to the structural domains of the polypeptide and has regional homology to the low-density lipoprotein receptor gene. Genomics 26: 219-228.

Fazio MJ, O'Leary J, Kahari VM, Chen YQ, Saitta B, and Uitto J (1991). Human nidogen gene: Structural and functional characterization of the $5^{\prime}$-flanking region. $\mathrm{J}$ Invest Dermatol 97:281-285.

Fox JW, Mayer U, Nischt R, Aumailley M, Reinhardt D, Wiedemann H, Mann K, Timpl R, Krieg T, and Engel J (1991). Recombinant nidogen consists of three globular domains and mediates binding of laminin to collagen type IV. EMBO J 10:3137-3146.

Gresham HD, Graham IL, Griffin GL, Hsieh JC, Dong LJ, Chung AE, and Senior RM (1996). Domain-specific interactions between entactin and neutrophil integrins: G2 domain ligation of integrin alpha3beta1 and $\mathrm{E}$ domain ligation of the leukocyte response integrin signal for different responses. J Biol Chem 271:30587-30594.

Haavik J and Toska K (1998). Tyrosine hydroxylase and Parkinson's disease. Mol Neurobiol 16:285-309.

Heinemann U, Gabriel S, Schuchmann S, and Eder C (1999). Contribution of astrocytes to seizure activity. Adv Neurol 79:583-590.

Hsieh JC, Wu C, and Chung AE (1994). The binding of fibronectin to entactin is mediated through the $29 \mathrm{kDa}$ amino terminal fragment of fibronectin and the G2 domain of entactin. Biochem Biophys Res Commun 199:1509-1517.

Hynes RO (1994). Genetic analyses of cell-matrix interactions in development. Curr Opin Genet Dev 4:569-574.

Janigro D (1999). Blood-brain barrier, ion homeostatis and epilepsy: Possible implications towards the understanding of ketogenic diet mechanisms. Epilepsy Res 37:223-232.

Kim S and Wadsworth WG (2000). Positioning of longitudinal nerves in C. elegans by nidogen. Science 288:150-154.

Kimura N, Toyoshima T, Kojima T, and Shimane M (1998). Entactin-2: A new member of basement membrane protein with high homology to entactin/nidogen. Exp Cell Res 241: 36-45.

Kingsmore SF, Barbosa MD, Nguyen QA, Ashley JA, Blaydes SM, Tchernev VT, Detter JC, and Lovett M (1996). Physical mapping of the beige critical region on mouse chromosome 13. Mamm Genome 7:773-775.

Kohfeldt E, Sasaki T, Gohring W, and Timpl R (1998). Nidogen-2: A new basement membrane protein with diverse binding properties. J Mol Biol 282:99-109.

Kuszak JR, Peterson KL, and Brown HG (1996). Electron microscopic observations of the crystalline lens. Microsc Res Tech 33:441-479.

Kuszak JR, Sivak JG, and Weerheim JA (1991). Lens optical quality is a direct function of lens sutural architecture. Invest Ophthalmol Vis Sci 32:2119-2129. 
Kvansakul M, Hopf M, Ries A, Timpl R, and Hohenester E (2001). Structural basis for the high-affinity interaction of nidogen-1 with immunoglobulin-like domain 3 of perlecan. EMBO J 20:5342-5346.

Laemmli UK (1970). Cleavage of structural proteins during the assembly of the head of bacteriophage T4. Nature 227:680-685.

MacVicar BA (1989). Transmitter- and voltage-activated ionic channels in astrocytes: Possible role in extracellular ionic homeostasis. Acta Physiol Scand Suppl 582:49.

Mann K, Deutzmann R, Aumailley M, Timpl R, Raimondi L, Yamada Y, Pan TC, Conway D, and Chu ML (1989). Amino acid sequence of mouse nidogen, a multidomain basement membrane protein with binding activity for laminin, collagen IV and cells. EMBO J 8:65-72.

Menko S, Philp N, Veneziale B, and Walker J (1998). Integrins and development: How might these receptors regulate differentiation of the lens. Ann NY Acad Sci 842:36-41.

Miner JH, Cunningham J, and Sanes JR (1998). Roles for laminin in embryogenesis: Exencephaly, syndactyly, and placentopathy in mice lacking the laminin alpha5 chain. $J$ Cell Biol 143:1713-1723.

Miyagoe Y, Hanaoka K, Nonaka I, Hayasaka M, Nabeshima Y, Arahata K, Nabeshima Y, and Takeda S (1997). Laminin alpha2 chain-null mutant mice by targeted disruption of the Lama2 gene: A new model of merosin (laminin 2)-deficient congenital muscular dystrophy. FEBS Lett 415:33-39.

Murshed M, Smyth N, Miosge N, Karolat J, Krieg T, Paulsson $M$, and Nischt $R$ (2000). The absence of nidogen 1 does not affect murine basement membrane formation. Mol Cell Biol 20:7007-7012.

Nagayoshi T, Sanborn D, Hickok NJ, Olsen DR, Fazio MJ, Chu ML, Knowlton R, Mann K, Deutzmann R, and Timpl R (1989). Human nidogen: Complete amino acid sequence and structural domains deduced from cDNAs, and evidence for polymorphism of the gene. DNA 8:581-594.

Nakae $H$, Sugano $M$, Ishimori $Y$, Endo $T$, and Obinata $T$ (1993). Ascidian entactin/nidogen: Implication of evolution by shuffling two kinds of cysteine-rich motifs. Eur $\mathrm{J}$ Biochem 213:11-19.

Noakes PG, Miner JH, Gautam M, Cunningham JM, Sanes JR, and Merlie JP (1995). The renal glomerulus of mice lacking s-laminin/laminin beta 2: Nephrosis despite molecular compensation by laminin beta 1. Nat Genet 10:400-406.

Norose K, Lo WK, Clark JI, Sage EH, and Howe CC (2000). Lenses of SPARC-null mice exhibit an abnormal cell surfacebasement membrane interface. Exp Eye Res 71:295-307.

O'Donnell ME, Martinez A, and Sun D (1995). Cerebral microvascular endothelial cell Na-K-Cl cotransport: Regulation by astrocyte-conditioned medium. Am J Physiol 268: C747-C754.

Olsen DR, Nagayoshi T, Fazio M, Mattei MG, Passage E, Weil D, Timpl R, Chu ML, and Uitto J (1989). Human nidogen: cDNA cloning, cellular expression, and mapping of the gene to chromosome lq43. Am J Hum Genet 44:876-885.

Pardridge WM (1991). Blood-brain barrier transport of glucose, free fatty acids, and ketone bodies. Adv Exp Med Biol 291:43-53.
Perou CM, Moore KJ, Nagle DL, Misumi DJ, Woolf EA, McGrail SH, Holmgren L, Brody TH, Dussault BJ Jr, Monroe CA, Duyk GM, Pryor RJ, Li L, Justice MJ, and Kaplan J (1996). Identification of the murine beige gene by YAC complementation and positional cloning. Nat Genet 13:303308.

Rayner DV (1996). Glucose transporters in the brain. Proc Nutr Soc 55:209-219.

Reing J, Durkin ME, and Chung AE (1992). Laminin B1 expression is required for laminin deposition into the extracellular matrix of PC12 cells. J Biol Chem 267:23143-23150.

Ryan MC, Lee K, Miyashita Y, and Carter WG (1999). Targeted disruption of the LAMA3 gene in mice reveals abnormalities in survival and late stage differentiation of epithelial cells. J Cell Biol 145:1309-1323.

Sasaki T, Gohring W, Pan TC, Chu ML, and Timpl R (1995). Binding of mouse and human fibulin-2 to extracellular matrix ligands. J Mol Biol 254:892-899.

Schlosshauer B (1993). The blood-brain barrier: Morphology, molecules, and neurothelin. Bioessays 15:341-346.

Senior RM, Gresham HD, Griffin GL, Brown EJ, and Chung AE (1992). Entactin stimulates neutrophil adhesion and chemotaxis through interactions between its Arg-Gly-Asp (RGD) domain and the leukocyte response integrin. J Clin Invest 90:2251-2257.

Smyth N, Vatansever HS, Meyer M, Frie C, Paulsson M, and Edgar D (1998). The targeted deletion of the LAMC1 gene. Ann N Y Acad Sci 857:283-286.

Timpl R and Brown JC (1996). Supramolecular assembly of basement membranes. Bioessays 18:123-132.

Vannucci SJ, Clark RR, Koehler-Stec E, Li K, Smith CB, Davies P, Maher F, and Simpson IA (1998). Glucose transporter expression in brain: Relationship to cerebral glucose utilization. Dev Neurosci 20:369-379.

Walz W (2000). Role of astrocytes in the clearance of excess extracellular potassium. Neurochem Int 36:291-300.

White HS, Chow SY, Yen-Chow YC, and Woodbury DM (1992). Effect of elevated potassium on the ion content of mouse astrocytes and neurons. Can J Physiol Pharmacol 70(Suppl):S263-S268.

Wu C and Chung AE (1991). Potential role of entactin in hemostasis: Specific interaction of entactin with fibrinogen $A$ alpha and B beta chains. J Biol Chem 266:18802-18807.

Wu C, Chung AE, and McDonald JA (1995) A novel role for alpha 3 beta 1 integrins in extracellular matrix assembly. J Cell Sci 108( Pt 6):2511-2523.

Wu C, Reing J, and Chung AE (1991). Entactin forms a complex with fibronectin and co-localizes in the extracellular matrix of the embryonal carcinoma-derived $4 C Q$ cell line. Biochem Biophys Res Commun 178:1219-1225.

Yurchenco PD and O’Rear JJ (1994) Basal lamina assembly. Curr Opin Cell Biol 6:674-681. 